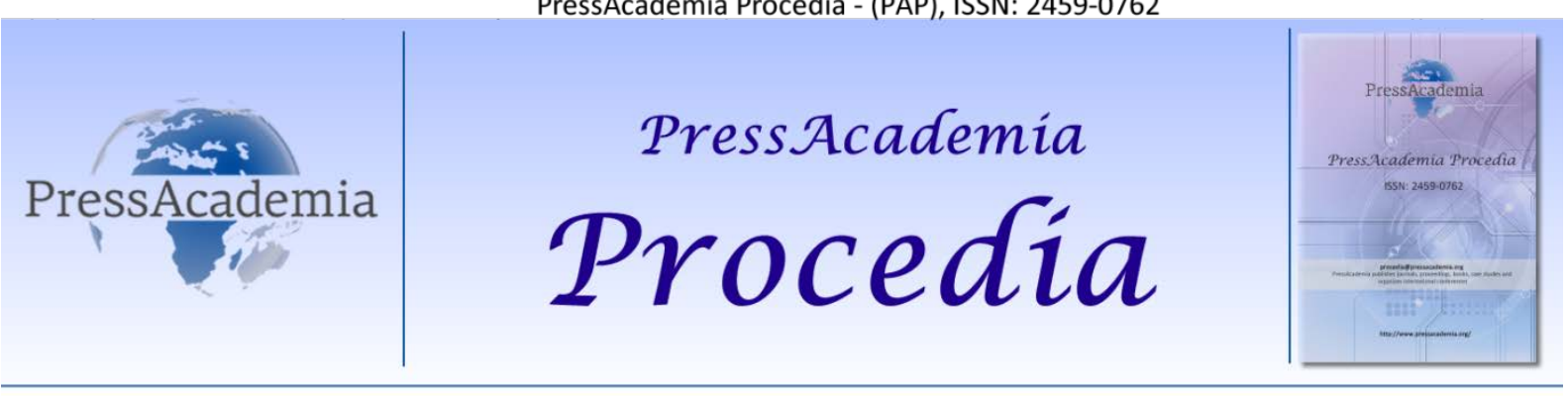

Global Business Research Congress (GBRC), June 4-5, 2015, Istanbul, Turkey.

\title{
CALCULATION OF CONTROL VALUE AND TURKISH FINANCIAL MARKETS
}

\section{DOI: 10.17261/Pressacademia.2016118138}

\author{
S. Saygın Eyupgiller ${ }^{1}$, Nebil Ilseven ${ }^{2}$ \\ ${ }^{1}$ Işık Universitesi. ssaygin.eyupgiller@isikun.edu.tr \\ ${ }^{2}$ Işık Universitesi. nebil.ilseven@isikun.edu.tr
}

\begin{abstract}
The question of Control Share Premium, more widely referred to as the "control premium" in the literature on corporate valuations is treated as a curious area of study by the academic and professional circles. This paper addresses the question of CSP primarily from a conceptual point of view. We point out, here, that, 1) corporate value drivers, summarized a "private benefits of control," that currently are evident and internal to the acquired businesses are the main determinant of the value of the CSP; 2 ) CSP is indeed relevant in Turkish financial markets; and, 3) The most meaningful approach to calculate control premiums in Turkish financial markets, as in other regions, would be to employ DCF methodology on the "set of private benefits" that are identified in the target company to be acquired based on its on corporate and sectoral merits. Another conclusion is that as CPS has a certain impact on the valuation of overall equity value of a firm, it has a significant impact on the position of minority shareholders with respect to the minority protection rights in the target company.
\end{abstract}

Keywords: Competency, competency perceptions, competency analysis, competency based recruiting, competency based management. JEL Codes: J24, M12, M53, 015.

\section{INTRODUCTION}

Turkish economy has been undergoing a markedly visible process of financialization in the recent decades. As the share of Financial Sector surged from $8 \%$ levels in 2003 to $12 \%$ of the GDP, financial sector has become a critical driving force in the economic development of the country. ${ }^{1}$ In terms of the asset size of the financial sector, the growth has been remarkable from around $80 \%$ of GDP in the early 2000s, the sector is currently thriving on approximately $137 \%$ levels of the GDP in Turkey. ${ }^{2}$ A closer look at the growth of sub-sectors in the industry reveals that this growth is, by far, a banking sector-driven growth as the asset size of of the banking institutions constitutes about $75 \%$ of the total assets of the financial markets in Turkey. The rest of the industry is composed of a whole range of financial actors like leasing companies, factoring companies, REITs, AMCs, insurance companies, pension funds, financial holding companies, securities investment trusts and the like.

In this broad spectrum of various institutions, the Central Bank of Turkey excluded, ISE market capitalization constitutes about $1 / 5$ th of the financial services market at TL $626 \mathrm{Bn}$ in 2014 . $^{3}$ What is more important here is

\footnotetext{
${ }^{1}$ Turkish Statistical Institute Data Base

${ }^{2}$ Banking Regulatory and Supervision Authority, Financial Markets Report, No. 26, June 2012, p.22.

${ }^{3}$ Borsa Istanbul, Annual Report 2014, p.35.
} 
the number of companies traded in the Stock Exchange and the number of investors trading in the Stock Exchange which is 386 and 1.075 million, respectively. ${ }^{4}$ Finally, the overall float in the Stock Exchange is about $40 \%$ in the first quarter of 2015 , of which about $65 \%$ is held by the foreign investors. ${ }^{5}$ Considering the difficulties in determining exactly who the end-beneficiaries of the foreign parties, investing in the Stock Exchange, one can nevertheless assume that the foreign ownership of the float is no less than $40-45 \%$ in the Stock Exchange.

The picture is very clear here that Borsa Istanbul, BIST (formerly the Istanbul Stock Exchange) remains a shallow and narrow market by all accepted criteria in the field. However, the activity continues in the market as private transactions continue to be executed. Ernst and Young reported 318 merger and acquisition transactions that were closed in the market in $2014 .^{6}$

Of these transactions, 130 deals disclosed transaction details, including price conditions. As such, disclosed deals were executed at USD 17.7Bn in 2014. The Company estimates that the remaining deals were closed at a total price of about USD 5 Bn during the same period, bringing the transaction volume in 2014 to a total of USD $22 \mathrm{Bn}^{7}$ Looking more closely at these transactions, we see that the average ticket size was USD $70 \mathrm{MM}$ in a group where 3 deals (state companies) were closed with valuations over USD 1 Bn each and 22 deals, over USD $100 \mathrm{MM}$ each. This shows that several of the remaining transactions involved SME-size companies in a broad sectoral distribution. ${ }^{8}$

This paper addresses the question of valuing control premium that a shareholder or a group of shareholders would be willing to undertake in acquiring a firm. As such, it is suggested that control value can become an important value-driver, itself, in determining the overall valuation of a firm. It may, concurrently, serve as a value-impairing factor, depending on how the market would perceive the controlling party would exercise its powers in the firm's ordinary course of business.

The paper is constructed in three main parts. In the first part, we try to construct the operational definition of "Control Premium" so as to shed light to and assist with a better understanding of the concepts and tools to be discussed in the proceeding sections. In this section, we note various characteristics of the concept of control value that serve as basis for calculation of control premiums in the industry. We also note in this section some of the non-financial characteristics of the topic with special emphasis on it legal foundations where rests the inner source of any value that control power in a corporation would project. Finally, we look, briefly, at the professional standards that underlie the professional works that are carried out in the financial services industry today.

In the second part, alternative methods of calculating control premium (control value) is discussed as put forth in various scholarly and professional studies. The paper places special emphasis here on the broad parameters of the "private benefits approach." Private Benefits Approach emerges in our study of control value as one which provides a broad theoretical grasp of the issue while offering practical methodologies to quantify this element of value in the overall exercise of corporate valuation. Here, the related non-financial factors are also highlighted as they affect the magnitute and relevance of control premium in a merger and acquisition transaction in financial markets.

In the third part, the paper examines the market dynamics and development of the regulatory and legislative structures that govern control value in financial markets in Turkey. Changing parameters, especially in the areas of corporate law, tax laws and applications, regulatory matters such as capital markets rules and regulations have a significant impact on control value in the markets. This section examines the position of the Turkish capital markets with respect to the presence of control value in contrast with comparable examples that are empirically tested in more mature markets abroad. This section also looks at the progress in these

\footnotetext{
${ }^{4}$ Ibid., p.36-37

${ }^{5}$ Ibid., p.37.

${ }^{6}$ Ernest and Young-istanbul, Mergers and Acquisitions Report Turkey, 2014, p.5

${ }^{7}$ lbid., p. 5-6

${ }^{8}$ Ibid., p. 6-7.
} 
essentially non-financial factors along with financial methods that are indigenous to the topic, and attempts to offer a general framework of understanding for the calculation of control premiums in Turkey.

\section{CONTROL PREMIUM: AN OPERATING DEFINITION OF THE TERM}

"A control premium is an assessment of additional equity value, over and above the value calculated on a prorata basis." ${ }^{9}$ Schubert and Barenbaum argue that additional value may come from a variety sources and reasons but they can all be classified under 3 categories: a) controlling party, dictating management decisions to create additional value; b) controlling party, allocating special benefits for itself; c) controlling party, accuring psychological benefits to his account. For control premium to have a positive value, having only the position of control does not constitute a sufficient grounds. The position of control must be used for the benefit of the firm, more specifically for the benefit of majority as well as minority shareholders. Again, having the control position does not guarantee better management of the firm than those in the minority position. Likewise, psychological effects are very difficult to assess by any objective measures as they will vary from one individual to another without necessarily positing a quantifiable trend. What remains here as a more measurable basis of valuing control premium is the special benefits that the controlling shareholding may allocate to himself and/or his friends and relatives.

Control premium has another distinct feature that differentiates it as a "value driver" than the others, such as the "acquisition premium." Most valuations are done based on equity value of the target firms. As such, they represent a value that is specific to the equity structure of the firm. Control premium, however, pertains to the whole of the firm where it is believed that value-drivers that currently accounted for exist regardless of the capital structure of the firm. Therefore, while discussing the control premium, it is important to note that operational and other non-equity related features carry greater weight as sources of potential synergies to be captured. ${ }^{10}$ This feature of control premium carries an important implication: as we talk about "comparables" in corporate valuation exercises, in general, when valuing control premium, we have to be extra cautious to go with the "comparables" as each and every firm may have different potential sources of control value that are unique to them.

A fourth possible base for control premium is mentioned as expectations for "creating synergistic gains" whereby a buyer may be planning to combine the acquired firm with other firms he owns to create a combined value for his portfolio. ${ }^{11}$ The marginal contribution of the most recent acquisition to the overall value of the pre-transaction portfolio may be both quite possible or impossible at the time of the transaction. However, in either case, the acquirer has a certain motive to build his portfolio of holdings and assumes the control premium on synergistic grounds. This motive brings us back to the distinctive feature of control premium as not being limited to or tied to equity value but other firm-level attributes or even out-of-the-firm considerations.

In developing an operating definition of control premium, Damodaran places a great deal of the "burden of proof" on the management of the firm to be acquired. He points out that the expected value of control in a merger and acquisition transaction "is the product of two variables: change in value from altering the way a firm is operated and the probability that this change will occur. ${ }^{12}$ Why does the managment factor become critical here? Because as value an existing company, we are faced with two choices: valuing the company as it is with the existing management team in place, arriving a status quo value of the company; or, valuing the company with a hyphothetical "optimal management" team and arriving another value, optimal value of the company. Control value of the company should, in this case, correspond to the difference between the status quo value of the company and the optimal value of the company. It is not unheard of at all that there are cases

\footnotetext{
9 Schubert, Walt, Barenbaum, Les (1991) “Control Premiums and the Value of the Closely-held Firm," Journal of Small Business Finance, Vol. 1: Iss. 2, pp. 156; available at: http//digitalcommons.pepperdine.edu/jef/vol1/iss2/5

${ }^{10}$ Pursel, Brad (2010), “Control Premiums; Application and Analysis"Business Valuation Publications LLC, article \# 11126, March 2010; p. 4

${ }^{11}$ Booth, Richard A. (2001), “Minority Discounts and Control Premiums in Appraisal Proceedings.” October 4, 2001; p. 3; available at: http://ssrn.com/abstract $=285649$

12 Damodaran, Ashwath (2005), "The Value of Control: Implications for Control Premiums, Minority Discounts and Voting Share Differentials;" p. 488; available at: http://people.stern.nyu.edu/adamodar/pdfiles/papers/controlvalue.pdf
} 
where control value may not represent a positive value at all cases. It is important to note that nonmarketability or other such factors will make it essential to apply a "control discount" on the optimal value, which, in some cases, would drive the control value to a negative level.

In summary, what is Control Premium? Having set aside the question on if it even exists or not, the market reality tells us that "control renders power and power implies value." So we know corporate control has a value, on the conditions that if it enables 1 ) making or influencing all the management decisions in the firm; 2) capturing the ability to benefit from the synergies that are available outside the firm with other economic entities; 3 ) changing the cost of capital of the firm by changing the capital structure of the company and 4) reducing the cost of capital by achieving greater diversity and scale. ${ }^{13}$ As such, Control Value is,

"the premium that describes the price paid by a set of market participants in order to acquire a controlling interest -It is also the difference between the price that would be paid by those market participants for the subject controlling interest (fair value) and, the value of marketable non-controlling interests in the subject business ("Foundation Value")

(It) represents the enhancement to value that market participants would expect to realize (and pay for) as a result of enhanced cash flows and/or reduced risk if they gain control over the subject business." ${ }^{14}$

\subsection{A Quick Look at the Legal Background}

The question of control value is an economic term in itself. Yet the source of value that control share derives essentially from legal grounds. Corporate Management at the very least represents an institution that is created by law. Law prescribes the position of the owners, the directors of the board, ordinary officers of the corporation. Berle and Means examine the evolution of the modern corporation and note that the dominant forces within the corporation may not be the designated officers and directors by law but individuals and other controlling groups who enjoy the necessary position in the larger structure of the corporate scheme. ${ }^{15}$ They also note that despite this contradictory situation, the power of these individuals and groups in dominating the firm may be complete and effective. As such Berle and Means cite legal cases that address the question of "corporate control," dating back from 1890s. One of these cases was ruled by Mr. Tafts, the circuit court judge, in 1893, regarding a contract between a company and a shareholder whereby the shareholder expected to make a profit. In Central Trust Company v. Bridges, Judge Tafts observed:

The vice of such contracts is not that they do not represent the real relation between the parties, but that they are contracts made by a corporation with one who exercises such an undue influence over the directors, by reason of his relaton to them as principal stockholder or otherwise, that it is inequitable and unconscionable for him by such influence to secure individual profit to himself at the expense of the corporation and its other stockholders and bondholders. ${ }^{16}$

This ruling was the genesis of the doctrine known in the law as "the doctrine of dominant stockholder. ${ }^{17 "}$ This term presently led to commonly recognized institution of "control" in corporations as legal entities.

\footnotetext{
${ }^{13}$ Harms, Travis W (2015), "The Market Participant Acquisition Premium," Mercer Capital Corporate Presentation, January19, 2015; p.16.

14 Ibid., p.18.

${ }^{15}$ Berle, Adolf A. Means, Gardiner C. (1991), The Modern Corporation and Private Property, USA: Transaction Publishers, New Jersey, p. 207.

${ }^{16}$ Ibid., p.209

${ }^{17}$ This brief statement from the ruling provides the profile of a "controlling shareholder" or a "controlling block of shareholder." Equally importantly, this statement views the control share in a broad sense, focusing not only on the rights of the providers of equity capital but also providers of debt capital. Considering the timing of this statement, we will see this approach coming back to agenda over a century later when the markets would engage in the debate about "control premium based on equity value vs.control premium based on enterprise value." (note by: S.Eyüpgiller and N.ilseven)
} 
Courts in other cases attempted to resrict or fully reject the notion of "control" powers in corporations. However, by the turn of the Century, as far as the legal system was concerned, the prevailing idea was that control cannot be prohibited but it can governed. Meanwhile the legal doctrine recognized three main areas where "control" manifest itself in corporate actions. First, control may "influence and induce the directors in exercising the power of the corporation." Second, control may perform certain acts itself such as, voting for directors, for amendments to the Charter, or to ratify past actions or directors. Third, control may perform acts " which nominally have nothing to do with the corporation but would gravely affect the future of the corporation." 18

The third characteristic of control that was accepted in the legal doctrine was the most revolutinary of the three and constitutes the basis of the subject-matter of this paper, too. It meant that as per this third characteristic of control, control is such concept that it can be sold. Courts, since early 1900s, have recognized the fact that control has to do not only with the day-to-day activities of the firm, but by sheer possibility of transferring to other holders of control, it can change the fate of the corporations. A New York Court admitted and in Stanton v.Schenk case that buying control was indeed buying power but instead of ruling in favor of the plaintiff argued that control power was an asset that belong to the company, therefore, whatever payments were to be done for that asset were to be done to the company treasury. ${ }^{19}$

Drawing, once again, on the experience of the U.S. markets, the State of Delaware emerges to be main point of registration of many corporations in the country. Therefore, when it comes to legal actions and cases of litigation, the rulings of the Delaware courts sets the industry standard in many of the issues that are related to corporate finance. In more recent years, courts have introduced a new concept in determining the value of control whereby they coined the term "fair value" as opposed to "fair market value" as denoted in IRS Revenue Ruling 59-60. This time, the courts may be taking into consideration the doctrine of "entire fairness" in dealing with the question of control value.

Matthews notes that the statute says that:

"the Court shall determine the fair value of the shares exclusive of any element of value arising from the accomplishment or expectation of the merger or consolidation. ${ }^{20,}$

Matthews continues to observe that Delaware Law does not provision for any adjustments to be recognized by a new controlling and the company must be valued as a going concern based on its current asset structure and existing opportunites and without regards to any potential synergies or other value creating actions. Consequently, should a form of control value exist in a given corporate action, that should be accounted in the base valuation of the company as a financial value but not stated seperately as a strategic value. (the doctrine of "entire fairness")

The same observation was also noted by Gilson and Bernard earlier that under the rulings of Delaware courts, a price is "fair" if analysts considered all relevant factors that may affect the value of a company's stock, including the additional amounts that a buyer would be paying for potential synergies or other expected benefits in a given transaciton. ${ }^{21}$ As such, we are back to the dictinctions between "fair value vs. fair market value" as the two may represent the transaction price or not depending on the "inclusiveness" of the analyst's work on the target company. However, it is pretty clear from the evolution of the legal doctrine that the primacy of "fair value" over "fair market value" is of essence in approaching the concept of control value.

We are not going to discuss, here, the validity of this argument any further in this paper. Nor do we intend to elaborate further the evolution of the legal doctrine on the concept of control value or control premium. The purpose to look into the historical development of the concept was to highlight and demonstrate that a) control value is a concept with long-dating roots in the legal doctrine; b) area of control interest in corporate

\footnotetext{
${ }^{18}$ Ibid., p.211-212.

${ }^{19}$ lbid., p.214-216.

${ }^{20}$ Matthews, Gilbert, “Misuse of control premiums in Delaware appraisals, ”Business Valuation Review, 27: 2008 , p. $107-118$.

${ }^{21}$ Gilson, Ronald, J. and Bernard, S. Black (1995), The Law and Finance of Corporate Acquisitions, 2nd ed., Foundation Press, New York.
} 
affairs is a "governed" area; c) the value of control must reflect a "fair value" concept which may be distinct from the "fair market value;" d) the value of control is, therefore, as much a topic of financial mathematics as it is corporation law and corporate governance. Thus, while any methods of mathematical calculations of control value must draw on legally veriable grounds, any legal actions concerning control value must equally draw on sound mathematical grounds.

\subsection{General Standards of Recognizing Control Premium}

American Society of Appraisers (ASA) have been studying the fundamental question about control value: What conditions are to be met in order for a certain change in corporate valuation to be recognized and confirmed as Control Premium? ASA started to develop the relevant business valuation standards in 1992 and the first standards regarding Premiums and Discounts were issued as BVS-VII in January 1996. Later on, BVS-VII was revised twice, in February 2001 and July $2008 .^{22}$ (see Table 1 below)

\section{Table 1: ASA BVS-VII Valuation Discounts and Premiums}

\section{Preamble}

A. This Standard must be followed in all valuations of businesses, business ownership interests, securities and intangible assets developed by all members of the American Society of Appraisers, be they Candidates, Accredited Members (AM), Accredited Senior Appraisers (ASA), or Fellows (FASA).

B. The purpose of this Standard is to define and describe the requirements for the use of discounts and premiums whenever they are applied in the valuation of businesses, business ownership interests, securities and intangible assets.

C. This Standard applies to appraisals and may not necessarily apply to limited appraisals and calculations as defined in BVS-I General Requirements for Developing a Business Valuation, Section II.C.

D. This Standard incorporates the General Preamble to the ASA Business Valuation Standards.

E. This Standard applies at any time in the valuation process, whether within a method, to the value indicated by a valuation method, or to the result of weighting or correlating methods.

\section{The concepts of discounts and premiums}

A. A discount has no meaning until the conceptual basis underlying the base value to which it is applied is defined.

B. A premium has no meaning until the conceptual basis underlying the base value to which it is applied is defined.

C. A discount or premium is warranted when characteristics affecting the value of the subject interest differ sufficiently from those inherent in the base value to which the discount or premium is applied.

D. A discount or premium quantifies an adjustment to account for differences in characteristics affecting the value of the subject interest relative to the base value to which it is compared.

\section{The application of discounts and premiums}

A. The purpose, applicable standard of value, or other circumstances of an appraisal may indicate the need to account for differences between the base value and the value of the subject interest. If so, appropriate discounts or premiums should be applied.

B. The base value to which the discount or premium is applied must be specified and defined.

C. Each discount or premium to be applied to the base value must be defined

D. The primary reasons why each selected discount or premium applies to the appraised interest must be stated.

E. The evidence considered in deriving the discount or premium must be specified.

F. The appraiser's reasoning in arriving at a conclusion regarding the size of any discount or premium applied must be explained.

Source: ASA Business Valuations Standards, 2009

According to the prevailing body of standards, there is a clear emphasis that is put on defining the conceptual and material base of a premium to be applied in valuation exercises. Another significant point that is

\footnotetext{
${ }^{22}$ American Society of Appraisers, ASA Business Valuation Standarts, BVS-VII, p.2; available at http://www.appraisers.org/docs/default-source/discipline_bv/bv-standards.pdf?sfvrsn=0
} 
highlighted here is that any premium to apply in a given valuation must represent a sufficient value to make a difference from that of the already existing "base value," "status quo" value of the property in question.

During the financial crisis that erupted in 2008 in international markets, the valuations of several firms had plummeted to level that went beyond the comprehension of the owners and managements of these firms. The management teams were arguing that corporate valuations did not reflect the fair value of these economic entitites due to the extraordinary market conditions. They argued that the "intrinsic" values of the companies commanded much better valuations and that higher than usual control values had to apply to reach more appropriate values for these entities. The increasing frequency of the debate compelled the market players to address this issue more formally and the Appraisal Foundation in the U.S. organized a Working Group to clarify the relevant parameters in calculating and accounting for control value in merger and acquisition transactions in the market. ${ }^{23}$

Control value, as a technical term, implies other meanings in addition to signifying an element of financial valuation in corporate finance. The term is used in several areas such litigation cases, legal applications and so on. Therefore, one must bear in mind that control premium value in corporate finance stresses the market participant perspective in financial markets and that it is essentially an economics term more so than its legal implications. Therefore, any valuation exercises on control premium must eventually be "expressable" numerically in financial terms.

Valuation Research Corporation, a U.S.-based consulting firm on business valuation draws attention to two factors that affect the fair valuation of controlling premiums. These factors are; improved cash flow and risk reduction. ${ }^{24}$ VCR points out that having a controlling interest in a firm should not justify an automatic application of an incremental premium on the valuation of the business. If a transaction is not likely to generate additional cash flows beyond and above its current levels; or, if the acquisition will not result in risk reduction in the operations of the company, then, it is argued that the material base of a control premium does not exist.

Appraisal Foundation Working Group-3 issued its initial recommendations on control value in 2013 in a detailed communique that included specific areas of potential value that would contribute to a positive control premium in merger and acquisition transactions. ${ }^{25}$ The Report made a very critical observation on one of the fundamental drivers of value that underlie control premium: command over management to undertake certain corporate actions that would justify control value. After citing close to 20 types of specific corporate actions, the Report came to the conclusion that having sheer control over management prerogatives does not automatically yield a "market participant value." The required condition here is that if such actions would result in enhanced cash flows, or reduced risks, or lower cost of capital or create working capital related efficiencies, than the economic benefits of these actions would likely transfer into control value for the market participant.

\section{AN OVERVIEW OF METHODS OF CALCULATING CONTROL VALUE}

\subsection{Zero Control Value Argument}

In the 1990s, scholars like Nath, Cornell and others argued that control value does not inherently carry a value and, therefore, does not constitute a relevant factor in corporate valuations. ${ }^{26}$ Nath was quite vocal in his argument that control prerogatives would apply in the post-transaction period with the introduction of a new management, new operational capacities and new capital structures and so on. As such, acquisition price of a corporation should not include any additional benefits to the seller. On the other hand, if the existing management structure were in a position to affect the necessary improvements already, rendering a greater

\footnotetext{
${ }^{23}$ Ibid., PURSEL, p.4

24"Market Participant Acquisition Premiums," VCR Alert, November 2013.

${ }^{25}$ Fishman, Jay E. (2013), "The Measurement and Application of Market Participant Acquisition Premiums," Appraisal Foundation Working Group-3 Discussion Draft, April 16, 2013.

${ }^{26}$ Nath, Eric (1990), “Control premiums and minority interest discounts in private companies,"Business Valuation Review, 9, 1990: p.3946;Nath, Eric (1994), “A Tale of Two Markets,"Business Valuation Review, 13: 107-112; Cornell, Bradford,(1992), Corporate Valuation, Business One Irwin, USA: New York.
} 
valuation for the company, then there would surely be investors in the market to note this potential and make the company a take-over target. This possibility was all the more relevant in the case of the public companies. However, the market observation indicated that only a fraction of the public companies in the market were subject to friendly or hostile take-over bids, a sign of zero or close-to-zero differential between the "fair market value" and "fair value" of the company, i.e. control value.

\section{2. "Levels of Value" Concept}

Mercer in 2007 and Pratt in 2008 observed that "corporate value" is a sufficiently complicated concept that it would be best grasped and analized when broken into its relevant components and stuided in detailed based on respective foundations of each component. A model is most powerful if it can depit an otherwise complicated scheme in simple terms. Mercer and Pratt introduced the concept of "marketable minority value" as the base value of any given economic and suggested to treat overall corporate value in three levels: a) marketable minority level, b) financial control level and c) strategic control level. ${ }^{27}$ Following illustration is a simplified version of the "Levels of Value" approach to identifying and calculating control value.

Figure 1

Levels of Value

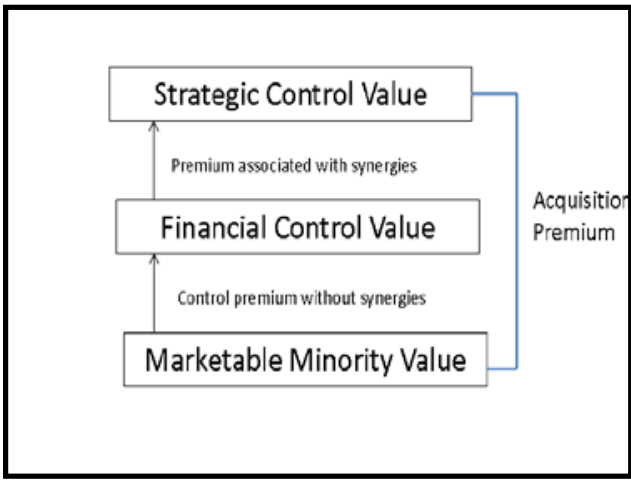

It is depicted here that the "base" value of a corporation is the implied value of the operational and organizational sources and activities of the as and how they exist presently and available for minority shareholders in the market or privately, whichever the case may be. One level up is a management-dependent level, often called, "bad management" level where a new management can be introduced to the company by the controlling shareholders for the enhancement of the overall financial performance of the company. Top level implies a different dimension of value, "synergic value," that can be achieved from internally but, more importantly, also from outside the corporation that controlling shareholders would be able to introduce or facilitate ${ }^{28}$. More detailed applications of Levels of Value approach is examined in the coming sections where numeric examples are considered related control value in corporations.

\subsection{Conditional Acceptance of Positive Control Value}

It was Nath (1990) who argued earlier that control should not yield any positive value in corporate valuations. About twenty years later, Nath, in a commentary article he prepared on Best Practices in Control Premiums, stated that positive values for control are a part of daily life and can indeed command positive values. ${ }^{29} \mathrm{He}$ observes that altough premiums for control are not technically justified and do not rest on empirically sound

\footnotetext{
27 Mercer, Christopher, Travis, Harms W. (2007), Business Valuation: An Integrated Theory, 2nd ed., USA: Wiley, New York; Prattt, Shannon (2008), Valuing a Business, 5th edition, USA: McGraw Hill, New York.

${ }^{28}$ Cornell, Bradford (2013), Guideline Public Company Valuation and Control Premiums: An Economic Analysis, p. 3-4; available at: http://people.hss.caltech.edu/ bcornell/PUBLICATIONS/2013\%20Cornell\%20-\%20Control\%20Premiums.pdf

${ }^{29}$ Nath, Eric W. (2011), "Best Practices Regarding Control Premiums; Comments regarding the Appraisal

Foundation's White Paper on Control Premiums," Journal of Business Valuation 2011:2; p.6.
} 
and proven grounds, premiums for control shares or controlling blocks are, nevertheless, continue to be paid in the market.

He, then, asks the question, Why? and brings three possible answers to his own question: First, he asserts that one can justifiably talk about a premium in cases where expected growth rate is, for instance, 10-15\% over the next five years while the price offered today correspondends to a $30 \%$ yield on a "bird-in-the-hand" basis. Yes, there is a certain difference in yield which exceeds the currently available value of the asset in question; enabling seller to realize her investment at a higher yield and sooner than exptected. This difference, Nath suggests, is actually an "acquisition" premium on the whole value of the transaction. ${ }^{30}$ He mentions in his analysis two other possible cases where payment of a certain premium may be justified. First case is a rather mechanistic situation where supply and demand dynamics in the market drives prices upwards and a certain positive price differential may naturally emerge as sellers strive to maximize the exit value of their holdings. Second case entails a rather psychological situation where the buyer as a potential controlling party makes a bid that would be expected to be high enough to get the consensus of the minority shareholders to ratify the new shareholding structure. ${ }^{31}$

In summary, Nath tells us that positive price differences between marketable minority value and the transaction value (acquisition premium) may and often times does emerge but there simply does not exist sufficient empirical proof to attribute this margin only to the control factor.

\subsection{Control Value as a Function of Change of Management}

Damodaran makes a case that control of the company would command a value in itself so long as control would translate into running the company differently and better than it is run presently. As such, he observes that the underlying factor in control value is essentially a question of management of the company's fundamentals. Control value, therefore, is a function of the majority shareholder's capacity to change the management of the company and the probability that she would successfully do it. ${ }^{32}$ Note here that Damodaran's approach to estimating control value rests on two elemets: 1) Actual change of management, itself, and, 2) the probability that such "change of guard" would actually materialize.

First, we look at how the actual change of management, itself, would effect the value of control, if any. As noted in Section I of this paper, Damodaran defines the current value of a company as the status quo value of the company. Status quo value implies that the company will continue to be run by the same management, employing the same supply and production schemes, with the same capital structure as the company rides the market conditions with the same corporate policies. In the second stage, he moves to define optimum value of the company, assuming that a meaningful management change is realized in the company, thereby, changing the fundamentals of the company drastically. In the final stage, he looks at the probability that such meaningful can and would be achieved by the new shareholder who is expecting to acquire the control shares of the company. As such, the difference between the status quo value and the optimum value gives us the control value of the company.

Figure 2, below, denotes the Status Quo Value of SAP Company. At the status quo level, the company has total assets of 31,615 , total equity of 34,656 , return on capital of $19.93 \%$ with share value of EUR 106,12 per share. At the status quo level, the Company has a weighted average cost of capital (COC) of $8.68 \%$ and a debt ratio of $14 \%$. Moreover, the Company has a cost of equity of $8.77 \%$ and cost of debt of $2.39 \%$. In terms of its operating performance, the Company is performing better than its peers in the market. However, a detailed study of the capital structure of the Company indicates to a very conservative financing policy where the finance managers appear to be under-utilizing the available sources of alternative financing to carry out the same level of operations in the market. ${ }^{33}$

\footnotetext{
30 lbid.

${ }^{31}$ ibid., p.7-8.

${ }^{32}$ ibid., DAMODARAN, p. 3 and p.42-46.

${ }^{33}$ Ibid., p. 18-21.
} 
In Figure 3, below, we are looking at the Optimum Value of the Company whereby the capital structure of the Company would be adjusted to its optimum level without any changes in the operational and organizational areas. In an alternative financial structure, available instruments and terms and conditions dictate an optimum debt ratio of $30 \%$, up from $14 \%$ at the status quo level with a cost of debt of $2.8 \%$. This adjustment, alone, reduces the WACC of the company to $7.96 \%$ from $8.68 \%$. This appears to be a small change in finance costs in the Company but the under the Optimum Value scenario, the equity value of the Company increases to 37,689 up from 34,656. Consequently, the fair value of the shares goes from EUR 106.12 per share to EUR 118.70. This increase amounts to an increase of EUR 12.58 per share, in other words, translating into a Control Share Premium of approximately $12 \%$ should such management change is realized in the Company by a controlling shareholder or controlling block of shares.

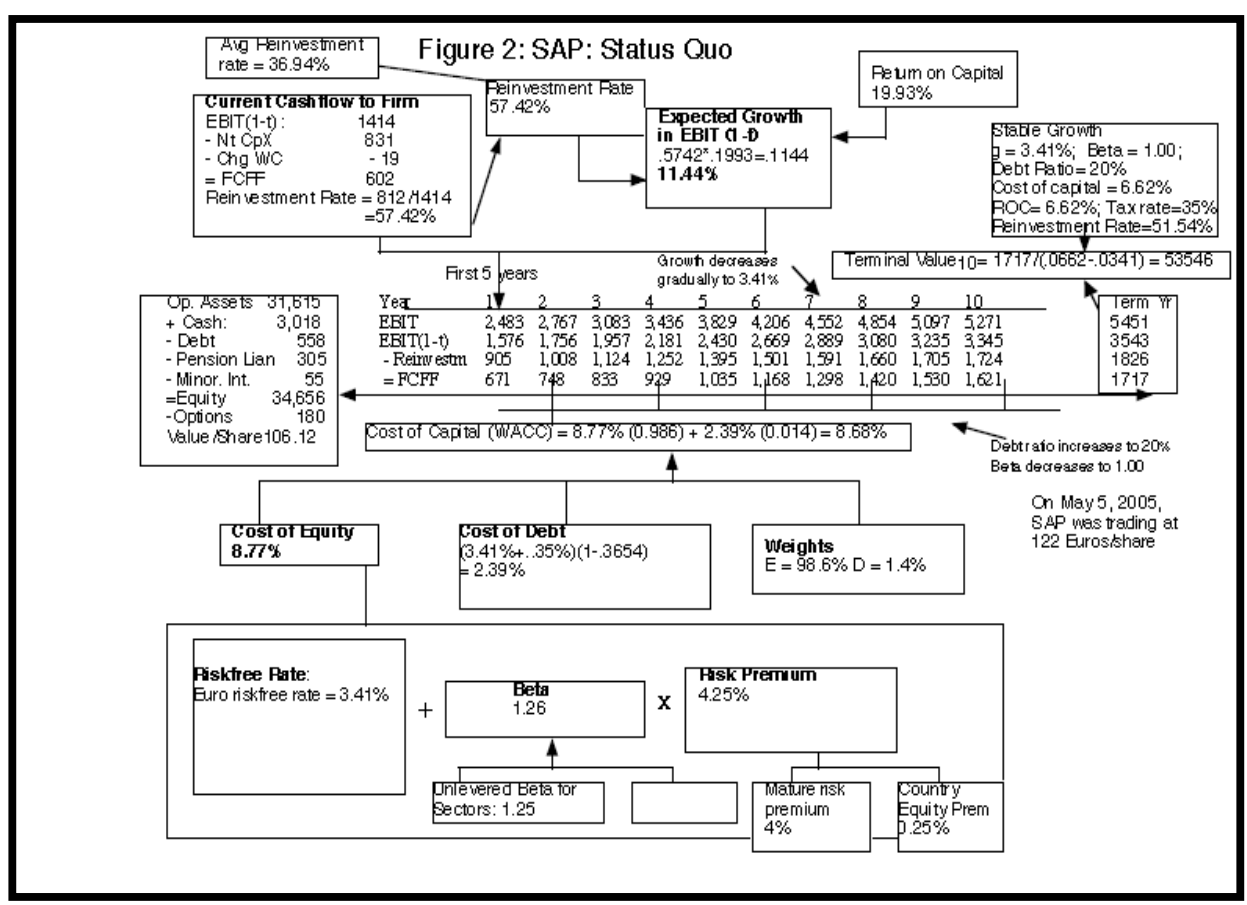

Source: DAMODARAN (2005) 


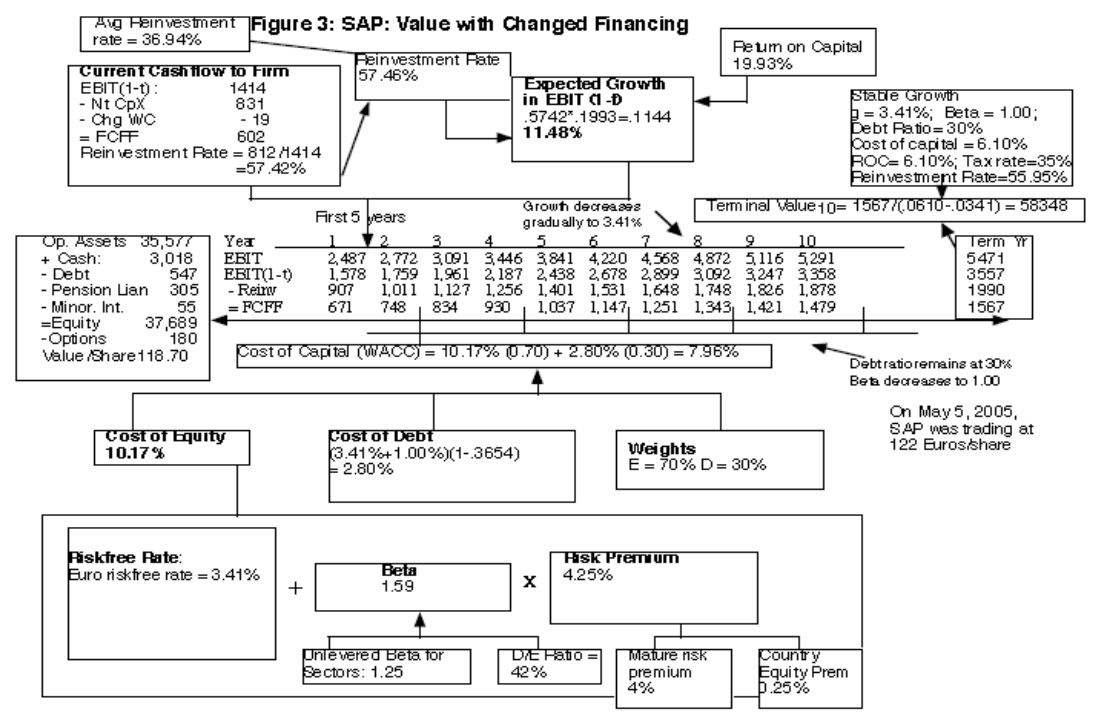

Source: DAMODARAN (2005)

Second, we can look at how the probably of management change actully happenning would effect control premium. Damodaran observes that probability of management change would be different across a distribution of diferent companies and different markets. Probability of change of management will be positively correlated to the strength of the shareholders and the effectiveness of the corporate governance structures in each individual firm. Probability of change of management, in itself, will change along with changes in the legal environment, market developments and shifts in investor behaviour and preferences through time. ${ }^{34}$ However, the fact that change of management and the probability of it to happen will continue to offer an important measure of control value in relevant cases of corporate actions. Table 2, below, gives the changes in equity value and price/share value of Blockbusters Company before and after a strong push by the controlling shareholders in $2005 .^{35}$

Table 2:Blockbusters Company Change of Equity Value and $\mathrm{P} / \mathrm{S}$ Value

\begin{tabular}{|l|l|l|}
\hline & Value of Equity & Value per share \\
\hline Status Quo & $\$ 955$ million & $\$ 5.13$ per share \\
\hline Optimally managed & $\$ 2,323$ million & $\$ 12.47$ per share \\
\hline
\end{tabular}

The stock was trading at roughly USD 8.20 per share at the status quo level and started to trade at USD 9.50 after the announcement of the actions to achieve optimum management level by the shareholders. Regarding effect of probability of management change $(P)$ actually happening and its effect on control value, we can use the following formula:

a) $\quad \mathrm{V} / \mathrm{s}_{\mathrm{m}}=\mathrm{V} / \mathrm{s}_{\mathrm{sq}}+\mathrm{P} *\left(\mathrm{~V} / \mathrm{s}_{\mathrm{om}}-\mathrm{V} / \mathrm{s}_{\mathrm{sq}}\right)$ where:

$\mathrm{V} / \mathrm{s}_{\mathrm{m}}$ is the Market Value per share,

$\mathrm{V} / \mathrm{s}_{\mathrm{sq}}$ is the Value per share at the status quo level,

$P$ is the implied probability of management change, actually happening,

and,

\footnotetext{
34 Ibid., p. 48-50.

35 Ibid,.p. 50.
} 


\section{$\mathrm{V} / \mathrm{s}_{\mathrm{om}}$ is Value per share at the optimally managed level}

Consequently, the implied probability $(P)$ that the market was attaching to a change in the value of the company BEFORE the control shareholder move is:

b)

$$
\begin{aligned}
8.20 & =5.13+P^{*}(12.47-5.13) \\
P & =(8.20-5.13) /(12.47-5.13) \\
P & =41.8 \%
\end{aligned}
$$

whereas, the implied probability $(P)$ that the market was attaching to a change in the value of the company AFTER the control shareholder move is:

c)

$$
\begin{aligned}
9.50 & =5.13+P^{*}(12.47-5.13) \\
P & =(9.50-5.13) /(12.47-5.13) \\
P & =59.5 \%
\end{aligned}
$$

What can we deduce from this relationship? It is clear in this case, the market is willing to pay a higher price for the company, indicating a higher level of belief that a management change will actually take place, carrying the company value closer to its optimum value level. Under the circumstances, the difference in marketable minority value corresponds to a $15.9 \%$ improvement. The value of control premium? That would certainly be another way of classifying this appreciation in share value.

Another version of the calculation of control value is based on differences in voting rights. Following is an example of how voting power, as another class of control right, would make a difference in share value vis a vis the non-voting shares, preference shares and the like.

To value voting and non-voting shares, we will consider Embraer, the Brazilian aerospace company. As is typical of most Brazilian companies, the company has common (voting) shares and preferred (non-voting shares).

We valued the company twice, first under the status quo and next under optimal management. With existing management in place, we estimated a value of 12.5 billion $\$ \mathrm{R}$ for the equity; this was based upon the assumption that the company would continue to maintain its conservative (low debt) financing policy and high returns on investments (albeit with a low reinvestment rate) at least for the near term.

We then revalued the firm at 14.7 billion $\$ \mathrm{R}$, assuming that the firm would be more aggressive both in its use of debt and in its reinvestment policy.

There are 242.5 million voting shares and 476.7 non-voting shares in the company and the probability of management change is relatively low, partly because the bulk of the voting shares are held by insiders and partly because the Brazilian government has significant influence in the company.

Assuming a probability of $\mathbf{2 0 \%}$ that management will change, we estimated the value per nonvoting and voting share:

Value per non-voting share = Status Quo Value/ (\# voting shares + \# non-voting shares)

$=12,500 /(242.5+476.7)=17.38 \$ R /$ share

Value per voting share $=$ Status Quo value $/$ sh + Probability of management change $*($ Optimal value - Status Quo Value)

$$
=17.38+0.2 *(14,700-12,500) / 242.5=19.19 \$ \mathrm{R} / \text { share }
$$

With our assumptions, the voting shares should trade at a premium of $10.4 \%$ over the nonvoting shares.

If the probability of management change increases, we would expect the premium to increase. 
Source: DAMODARAN (2005), p. 55.

\subsection{Control Premium and Characteristics of Ownership}

We had already discussed a simplified version of Nath's approach to "Levels of Value" concept in determining if control value existed at all, and, if did, at what exact level of value it would be appropriate to study it. Pratt, in his study of business valuation, suggests that levels of value could be segmented into its components with respect to characteristics of ownership in a corporation. ${ }^{36} \mathrm{He}$, then, looks at various sources of value in terms of not premiums, only, but discounts, also. Finally, he reaches a progressive system of "value ladder" as it effects the interests of different classes of owners in the company. Figure 4, below, provides a summary of the "value ladder" in building up enterprise level value and where and how premiums and discounts affect overall corporate value.

In this analysis, Pratt is providing a summary of several concepts in one caption. He is making a distinction between minority shares vs. control shares which is the main subject-matter of this paper. He also makes a reference to marketability and non-marketability of shares. He looks at levels of value in terms of strategic vs. non-strategic shares and, finally, in terms of controlling vs. non-controlling shares.

Based on the above hypothetical example, Pratt observes that control value corresponds to the difference between marketable value of shares (status quo value, base value) and the optimally managed value of shares. What is distinctly different from other approaches is that Pratt differentiates control value from synergistic value and treats synergistic value outside the definition of control value. This is a unique in the relevant literature where we observe in our review of various approaches a completely opposite treatment synergistic value. How is the value of control premium or of the synergistic value or the two combined calculated? Proponents of Levels of Value concept address this question in three areas: Income Approach, Market Approach and Asset-based Valuation Approach, through deployment of DCF, CAPM, mark-to-market and similar techniques as and where they may apply based on the merits of each case in question ${ }^{37}$.

Figure 4: Levels of Value in terms of Characteristics of Ownership

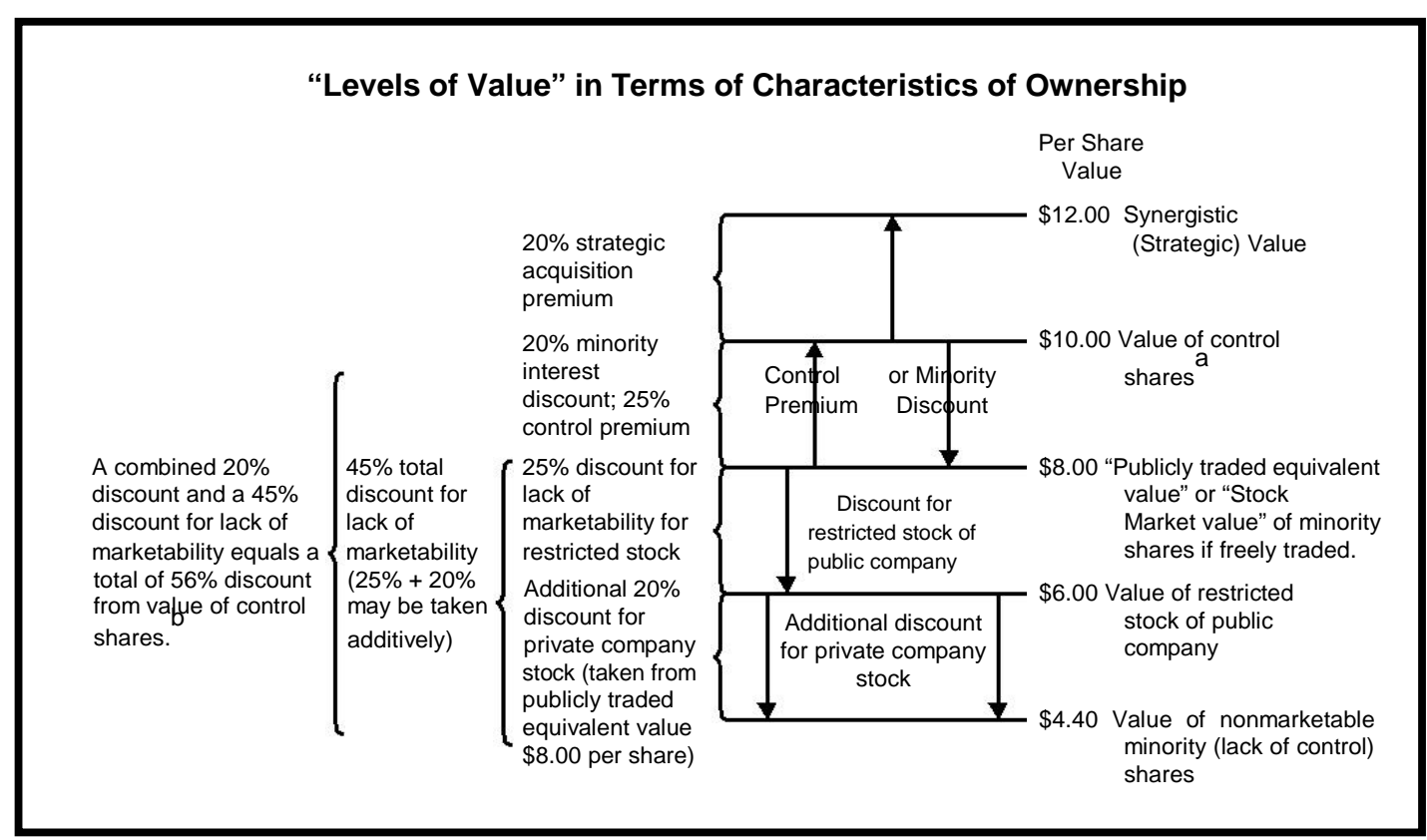

\footnotetext{
${ }^{36}$ Ibid., PRATT, p. 4-6

${ }^{37}$ Ibid., p. 8-10.
} 


\section{Source: PRATT (2009), p.5.}

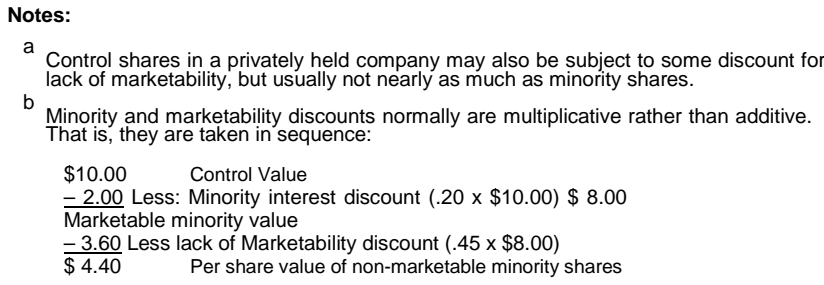

\subsection{Private Benefits of Control Argument}

Private Benefits of Control (PBC) are defined simply as "benefits not available to minority shareholders." ${ }^{38}$ These are benefits that entail transfer of value from minority package owners to owners of a controlling package through extra benefits or conveniences to the managing board, concluding contracts with extramarket terms, overpaying of services rendered by certain service provider and the like. Sepe also observes that PBC need not necessarily include terms that are detrimental the interests of minority shareholders. Certain synergistic actions that control owners have the capacity to effect can contribute to increase in overall corporate value without hampering the position of minority owners. These actions may include realization of value-creating business opportunities that were otherwise not possible or preferred without the input of control owners.

Coates defines PBC as follows: “...all benefits derived by the shareholder disposing of a control package and which are not shared with minority shareholders adequately to their share in the ownership structure". ${ }^{39} \mathrm{He}$ distinguishes PBC in three categories as; 1) "bad" benefits of control. Control owner actions in paying of excessive remunerations, assigning of different type bonuses related with a function performed, transferring benefits from the company through so called self-dealing transactions, excessive aversion to risk, making suboptimal strategic or operational decisions aiming at satisfying of personal interests of the shareholders disposing of a control package. These actions not only results in transfer of value from minority owners but lowers the oveall valuation of the company with accompanying social costs, also. 2) "good" benefits of control. Control owner actions that do not directly effect the operating activities of the firm but, while providing not necessarily financial benefits for the control owner, enhace corporate value at the "strategic" level. 3) "inherent" benefits of control. Actions that Control owners take by virtue of their control position in the natural flow of business such as enjoying autonomy and right to conclusive action in exchange for costs on the overall corporation like lower expected rate of returns and the like.

\subsubsection{Calculating Private Benefits of Control}

A very difficult task, indeed, for all the ambiguities and complexities the concept inherently imply in the practial world. In this paper, we examine the question of calculating the value of private benefits in three main sections: i) Functional Structure of Ownership Structure and the Size of Perquisites, ii) Transfer of Perquisite Values, and, iii) Level of Calculation.

\section{i) Functional Structure of Ownership Structure and the Size of Perquisites}

Dick and Zingales develop a theoretical framework for calculating PBC based on the definiton of the term that is quite in line with other referenced definitions in this paper. They note that private benefits of control are frequently defined as the "psychic" value some shareholders attribute to simply being in control. Although they view this definition as relevant a definiton as any other, they point to perquisites that are enjoyed by control owners as, if not the most important, but one of the main base of private benefits of control. ${ }^{40}$ Their

\footnotetext{
${ }^{38}$ Sepe, S.M. (2010), "Private Sale of Corporate Control: Why the European Mandatory Bid Rule is Inefficient," Arizona Legal Studies Discussion Paper No. 10-29. Available at SSRN: http://ssrn.com/abstract=1086321

${ }^{39}$ Coates, J.C.,Ownership, takeovers and EU law: how contestable should EU corporations be?; The Harvard John M. Olin Discussion Paper Series: http://www.law.harvard.edu/programs/olin_center/, Discussion Paper No. 450, 12/2003, ISSN 1045-6333

${ }^{40}$ Dick, Alexander, Zingales, Luigi (2002), "Private Benefits of Control: An International Comparison, p. 1-2; available at https://ideas.repec.org/p/nbr/nberwo/8711.html
} 
definition of private benefits of control is basically the net present of the opportunities and perquisites that are enjoyed by a shareholder or group of shareholders that minority shareholders cannot benefit from.

Having reached this conclusion, Dick and Zingales make two general observations that, to our understanding, are very critical to note in arriving a sound understanding of the value of private benefits of control in corporations. ${ }^{41}$ One, is that private benefits of control do not always represent positive values but it may sometimes imply additional costs to the control owner. Second, is that private benefits of control do not always render inefficiencies on minority owners but often facilitate value-creating transactions, too, making otherwise neglected or impossible operational and strategic transactions into the realm of the corporations. These two observations are in line with the other definitions and findings that are referred to in other sections of this paper and help us substantially conceptualize the relevant space of thinking in this topic.

Examining the theoratical method that Dick and Zingales introduces, the methodology in the following Box 1 is one of the empirical approaches that we can employ in estimating the value of control premium in related corporate transactions. ${ }^{42}$

Let $\lambda$, on the interval $[0,1]$, be the bargaining power of the controlling shareholder selling out, $B_{s, b}$ the level of private benefits extracted by the seller (buyer), and $Y_{b, s}$ the level of security benefits generated by the seller (buyer), then the price P paid for a controlling block of shares with acashflow rights, on the interval $[0,1]$ corresponds to the value transfered to the "buyer" of control stake by the "seller" of the current control owner at the extent of their respective bargaining powers with eachother as expressed in cash value.

Expressed in different terms, control value premium, $P$, is the difference in buying and selling value of the private benefits enjoyed by the control owner either a) as adjusted to the value of the cashflow rights on te underlying security interest or $b$ ) as adjusted to market imperfections as denoted below.

Box 1:Calculating the estimated Control Value 


$$
P=\lambda\left(B_{b}+\alpha Y_{b}\right)+(1-\lambda)\left(B_{s}+\alpha Y_{s}\right)
$$

and the per share price of the controlling block equals

$$
\frac{P}{\alpha}=\frac{\lambda B_{b}+(1-\lambda) B_{s}}{\alpha}+\lambda Y_{b}+(1-\lambda) Y_{s}
$$

To compute the control premium Barclay and Holderness (1989) subtract from (2) the price prevailing in the market after the announcement that control has changed hands, which should equal to $Y_{b}$. Thus, they obtain

$$
\frac{\lambda B_{b}+(1-\lambda) B_{s}}{\alpha}-(1-\lambda)\left(Y_{b}-Y_{s}\right) .
$$

They then multiply this price difference by the size of the controlling block $\alpha$. Hence, their estimate of private benefits of control

$$
B=\lambda B_{b}+(1-\lambda) B_{s}-\alpha(1-\lambda)\left(Y_{b}-Y_{s}\right) .
$$

of the private benefits of control the buyer expects to enjoy. When the market is not perfectly competitive, $B$ represents a weighted average of the private benefits of the seller and those of the buyer, adjusted for the difference in their security value.

To grasp the sense of this correction, let us consider the extreme situation where the buyer has all the

bargaining power and thus buys the controlling block at the seller reservation value $\quad\left(\frac{P}{\alpha}=\frac{B_{s}}{\alpha}+Y_{s}\right.$ ). In such a

In such a case the proper adjustment factor would be the market price before the announcement of the change in control.

As a result, $B$ calculated as in (4) will tend to underestimate the average private benefits of control enjoyed by the controlling party whenever $Y_{b}>Y_{s}$. Hence, the need for a correction.

\section{Source: DICK and ZINGALES(2002) p.9-11.}


This method serves as a sound basis for analyzing the levels and direction of control share premium in the public market. It provides sound and practical approximations on markets, sectors or groups of companies with periodic and consistent disclosure of relevant data to derive reliable conclusions on public market developments. Regarding the application of this model, it is all the more difficult to obtain consistent and quality data on private benefits of control on an industry level approach. In private market transactions, each case needs to be treated on its own merits. Public market comparables, on the other, might serve as rough comparables in reaching final price levels.

\section{ii) Transfer of Perquisite Values}

Of all the motives and classifications of private benefits of control, value of perquisites remains the area that is measurable and verifiable in determining the extent and size of control share premiums in corporate finance transactions. Barenbaum and Schubert argue that perquisites have an impact on control benefits in two ways. $^{43}$ First, the size of perquisite flows directly contributes to the value control premiums. Second, control premiums are relevant only to the extent monetary flows can be diverted to control owners from minority interests.

As such, one method of calculating control premiums is to look into the proportinate monetary interests of minority owners that will be the basis of control premiums to be transfered to control block owners in the company. One important point here is that the "yield" of control value is inversely correlated with the percentage ownership in a company. Very simply put: let us assume that the total annual value of control benefits amounts to USD 100.000. A control owner with $90 \%$ shareholding position would be extracting USD 10.000 of control benefits in a year. Alternatively, an $80 \%$ shareholding position would yield USD 20.000 in control benefits, a $100 \%$ increase in yield against $11 \%$ lower ownership in the company.

Measurement of control premiums can be divided according to pro-rata ownership in a standard DCF model as the following:

$$
\frac{P *(1+g)}{k-g}=\frac{P * \mathrm{~m} *(1+g)}{k-g}+\frac{P *(1-m) *(1+g)}{k-g}
$$

where: $\quad P=$ dollar value of the total control benefits in the company

$\mathrm{m}=$ percentage shareholding position of the minority shareholder(s)

$\mathrm{g}=$ constant rate of growth of control benefits

$\mathrm{k}=$ required rate of return

This formula expresses the two components of the total value of control benefits as the following:

$\begin{gathered}\text { Total Value } \\ \text { of Perquisites }\end{gathered}=\begin{gathered}\text { Minority Share } \\ \text { of Perquisites }\end{gathered}+\begin{gathered}\text { Majority Share } \\ \text { of Perquisites }\end{gathered}$

As Control Benefits are an expression of marketable minoirty benefits, Control Premium is calculated as:

$$
\mathrm{CP}=\frac{P * m *(1+g)}{k-g}
$$

\footnotetext{
${ }^{43}$ Schubert, Walt, Barenbaum, Les,(; "Control Premiums and the Value of the Closely-held Firm," Journal of Small Business Finance, 1: 2; p. 157; available at http://digitalcommons.pepperdine.edu/jef/vol1/iss2/5
} 
To give a numeric example: let us suppose that the company has an after-tax income of USD 100.000 in a given year where there is a $75 \%$ control owner. A detailed audit of the company reveals that the total value of the perquisites, $\boldsymbol{P}$, during the year totalled USD 50.000. This amount increases the after-tax profits of the company to USD 150.000 . The estimated growth rate of earnings, $\mathbf{g}$, is $5 \%$ and the required rate of return, $\mathbf{k}$, is $25 \%$.

Following Barenbaum and Schubert's using of the Gordon Model to value the equity of a company, the value of the company's total equity, $\boldsymbol{V}_{\boldsymbol{t}}$ is calculated as the following:

1)

$$
\begin{aligned}
& V_{t}=(150.000 * 1 *(1+.05)) /(.25-.05) \\
& V_{t}=787,500
\end{aligned}
$$

However, due to perquisites that accrued to the account the control owners, this value does not accrue the accounts of by the control owners and minority owners proportionately. Control owners receive an extra 65,625 coming from perquisite value in addition to their pro-rata value from the total equity value of the company. The value of the total control benefits that accrue pro-rata to the account of minority owners, $\boldsymbol{V}_{P, m}$ who do not benefit from is calculated below:

2)

$$
\begin{aligned}
& V_{P, m}=(50.000 * .25 *(1+.05)) /(.25+.05) \\
& V_{P, m}=65,625
\end{aligned}
$$

This means that the shreholders, receiving their share of equity value as 590,625 for control owners and 196,875 for minority interests, respectively, the allocation of value under the control share value becomes, $656,250(590,625+65,625)$ for control owners and 131,250 $(196,875-65,625)$ for the minority interests, respectively. This result indicates to a control benefit premium of about $11 \%$ for the majority shareholders as it corresponds to a minority discount of about $33 \%$ for the minority shareholders based on marketable minority valuation of the company in calculation 1 , above.

\section{ii.i) Calculating Point of Indifference (Z) between Perquisites and Reinvestment Decisions}

Schubert and Barenbaum raise an important question here. They, like do the other observers, try to understand how the preferences of control owners would be effected should the company be able to reinvest the perquisites with higher returns in other uses instead of accruing them to their own accounts. This is a perfectly justified question in grasping the degree of significance control benefits imply with respect to other alternative areas of use of available ccash flows in the company ${ }^{44}$. They apply a simple model to determine the yield of control benefits in comparison with the return on investments into alternative uses as the following:

$$
z=\frac{(1+r)}{(1-m)}-1
$$

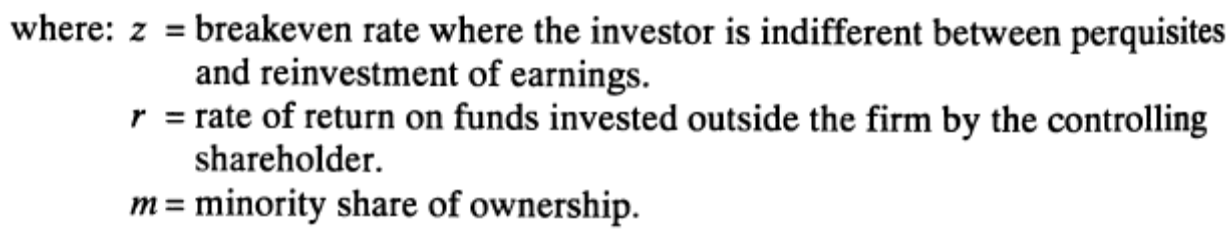

Put in an example;

\footnotetext{
${ }^{44}$ Ibid., p. 158-159
} 
1) if $m=0$, meaning that $100 \%$ of the company is owned by the same shareholder or group of shareholders, then, available cash flow can be placed in any investmet where $r$ would yield the highest returns.

2) Where $m>0$, meaning, there are indeed minority shareholders in the company, it almost certain that the control owners will prefer to receive perquisites instead of placing funds in other uses, including dividends. Numerically stated, let us assume that Company $A$ is owned $75 \%(1-\mathrm{m})$ by a one shareholding group, and the alternative rates of returns for funds in the market $15 \%(r)$. What would be the break-even yield of control benefits for the control owners to be indifferent between accruing perquisites and placements outside the company? Solving the equation for the given values, we get:

$$
\begin{aligned}
& Z=((1+.15) /(1-.25))-1 \\
& Z=53.3 \%
\end{aligned}
$$

Meaning, perquisites would earn for the control owners 3.5X what can be earned in placements outside the company.

\section{iii) Level of Calculation}

We have looked at various methods of estimating and/or calculating control benefits as they would effect the company valuations. At this point it is important to look at the question of level of calculation. Here, we are mainly looking at two levels; 1) Equity Level and 2) Enterprise Level.

All the arguments and observations we have looked, so far, address control benefits as sources of cashflow that a given group of shareholders receive but others do not within the realm of actual operations of the company. These benefits either derive from cost-savings in financial activities or synergetic moves in marketing and sales operations or management efficiencies in daily business conduct or direct transfers of benefits from internal cashflows through preferential actions in favor of control owners and so on as they are reflected on the equity value of respective shareholders.

In other words, control benefits stem not from actions that not related to and specific to equity holdings of owners but from actions taken in the operational activities of the firm. Control Benefits originate from and reflect operationals structure of a company. Therefore, it is only natural that control benefits are calcualted at the Enterprise Level where they are created and not at the Equity Level where they are consumed.

Travis Harms of Mercer Capital looks at the question of level of calculating control premiums in a recent corporate presentation. ${ }^{45}$ Harms observes that quantification of economic benefits of control focuses on operational factors like cash-flow enhancing and risk-reducing activities of the companies. He concludes, therefore, that Enterprise Level calculations of control benefits would be more consistent with the underlying factors, influencing the premiums. Following is a numeric example of how calculation of premiums would compare based on level of calculation:

\begin{tabular}{lrrrr} 
& $\begin{array}{c}\text { Marketable } \\
\text { Non-controlling }\end{array}$ & & Fair Value \\
\cline { 2 - 2 } Enterprise Value & $\mathbf{\$ 4 , 7 1 5}$ & & $\mathbf{\$ 6 , 3 5 4}$ \\
Interest-Bearing Debt & 1,716 & & 1,716 \\
Equity Value & $\$ 2,999$ & & $\$ 4,638$ \\
Shares Outstan ding & 300.0 & & 300.0 \\
Fair Value per Share & $\$ 10.00$ & & $\$ 15.46$ \\
MPAP (Equity) & & & $54.6 \%$ \\
MPAP (Enterprise Value) & & & $\mathbf{3 4 . 7 \%}$
\end{tabular}

\section{Source: HARMS (2015)}

\footnotetext{
${ }^{45}$ Harms, Travis W. (2015), "The Market Participant Acquisition Premium," 2015 OIV International Business Valuation Conference, Milan, Italy, January 19, 2015, p.20-21. Available at http://www.forumtools.biz/oiv/upload/TravisHarmsOIVPresentation.pdf
} 


\section{Control Share Premium and Turkish Capital Markets}

Control Share Premium is "accepted" as an important part of company valuations in Turkish financial markets, also. However, both the legal grounds on which this concept is treated and the available data on how relevant calculations are constructed provide highly limited information to get a sound understanding how Control Share Premiums are calculated in the market. The difference between public markets and private market is a complicating factor as there is even more limited access to transaction details in private market transactions.

Two questions are raised here: 1) Do control premiums exist in Turkish financial markets; 2) When we do get abnormal price differences in transactions which the market refers to as indications of control premiums, are we really measuring control premiums? are we looking at some other indications like over-pricing, miscalculations, the effect of momentarily high liquidity in the market or some other reasons?

Zingales, in his analysis of an international panel of transactions in 1990-2000 that took place in public markets in 39 countries. $^{46}$ Turkey is one of the countries that they examined in this study together with other factors that effected the size and relevance of control premiums that were realized in these markets.

In another study of the Turkish financial markets, we refer to a study that was done by Hekimoğlu and Tanyeri in 2011. They look at a panel of 125 transactions based on the hand-collected data in July 1991-July 2009 and measure cumulative abnormal returns (CAR) on stock market transactions where mergers and acquisitions of block shares were involved. In their analysis, they look at transactions that did not only involve purchase of control shares but already-controlling shares, purchasing new shares and other combinations, also. ${ }^{47}$

Both of these studies answer the first question positively that control share premiums are relevant in Turkish financial markets and they are measurable. Regarding the second question, Dick and Zingales address this issue directly. They look at various estimates for control value in different countries, they look at the nature of the institutional structure in various markets and compare their findings with specific cases to conclude that Yes, the findings that their model estimates correspond to actual control premiums. ${ }^{48}$ Hekimoğlu and Tanyeri, on the other hand, look at CAR values that they get and suggest that abnormal returns do reflect the size of relevant control premiums in the market. ${ }^{49}$

Both studies look at the market from two different perspectives. Therefore, it would be important to examine briefly the two different approaches to have a better understanding of control share premiums that are reflected in the market.

First, let us look at the Dick and Zingales's analysis of the international data. They look at 412 sample transactions in total. They also look at transactions, involving a 20 percent threshold in actual deals. Finally, they look only at markets where at least 2 qualifying transactions exist. They use the regression method by Barclays and Holderness, as described earlier in this paper, that focuses on price differences between the price paid by the controlling party and the market price.

The block premia is computed by taking the difference between the price per paid for the control block and the exchange price two days after the announcement of the control transaction, dividing it by the exchange price two days after the announcement and multiplying the ratio by the proportion of cash flow rights represented in the controlling block. ${ }^{50}$ Finally they look at Turkish stock market between $1991-2000$ where the number of listed companies increased from 125 in 1991 to 387 in 2000. ${ }^{51}$ In addition to the raw control block premium as percent of firm equity, they look at how the premiums vary based on a number of other variables as the following:

\footnotetext{
${ }^{46} \mathrm{Ibid} .$, DICK and ZINGALES, p. 13.

${ }^{47}$ Hekimoğlu, Mert Hakan, Tanyeri, Başak (2011), "Stock Market Reactions to Mergers of Non-financial Turkish Firms;" p. 8-9. Available at: http://papers.ssrn.com/sol3/papers.cfm?abstract id $=1768015$

${ }^{48}$ Ibid., DICK and ZINGALES, p. 21-23.

${ }^{49}$ Ibid., HEKIMOĞLU and TANYERI, p. 12-13.

${ }^{50}$ Ibid., DICK and ZINGALES, p.42.

${ }^{51}$ Ibid., Appendix - Table 2 drawn from Datastream.
} 
Table 3: Block Premium as Percent of Firm Equity

\begin{tabular}{|c|c|c|c|c|c|c|c|}
\hline Country & mean & median & $\begin{array}{l}\text { standard } \\
\text { deviation }\end{array}$ & minimum & maximum & $\begin{array}{c}\text { Number of } \\
\text { abservations }\end{array}$ & $\begin{array}{c}\text { Number of } \\
\text { positive } \\
\text { abservations }\end{array}$ \\
\hline Turkey & 0.30 & 0.09 & 0.55 & -0.03 & 1.41 & 6 & 5 \\
\hline averageinumber & 0.14 & 0.11 & 0.18 & -0.04 & 0.48 & 412 & 300 \\
\hline
\end{tabular}

According to Table 3, a total of 6 transactions were identified that involved a price difference between the announced price of acquisition and the market price. In one of these cases, a negative premium was observed. On the others, the average control premium was estimated as $30 \%$ over the equity value of the targeted companies in the group while the median value for control premium was estimated as $9 \%$. Looking at the overall data in this analysis, the mean was $14 \%$ while the median premium $11 \%$. During this period the highest average premium was measured as $65 \%$ for Brazil and the lowest as $2 \%$ in most of the OECD members.

Table 4: Block Premium as Percent of Firm Equity

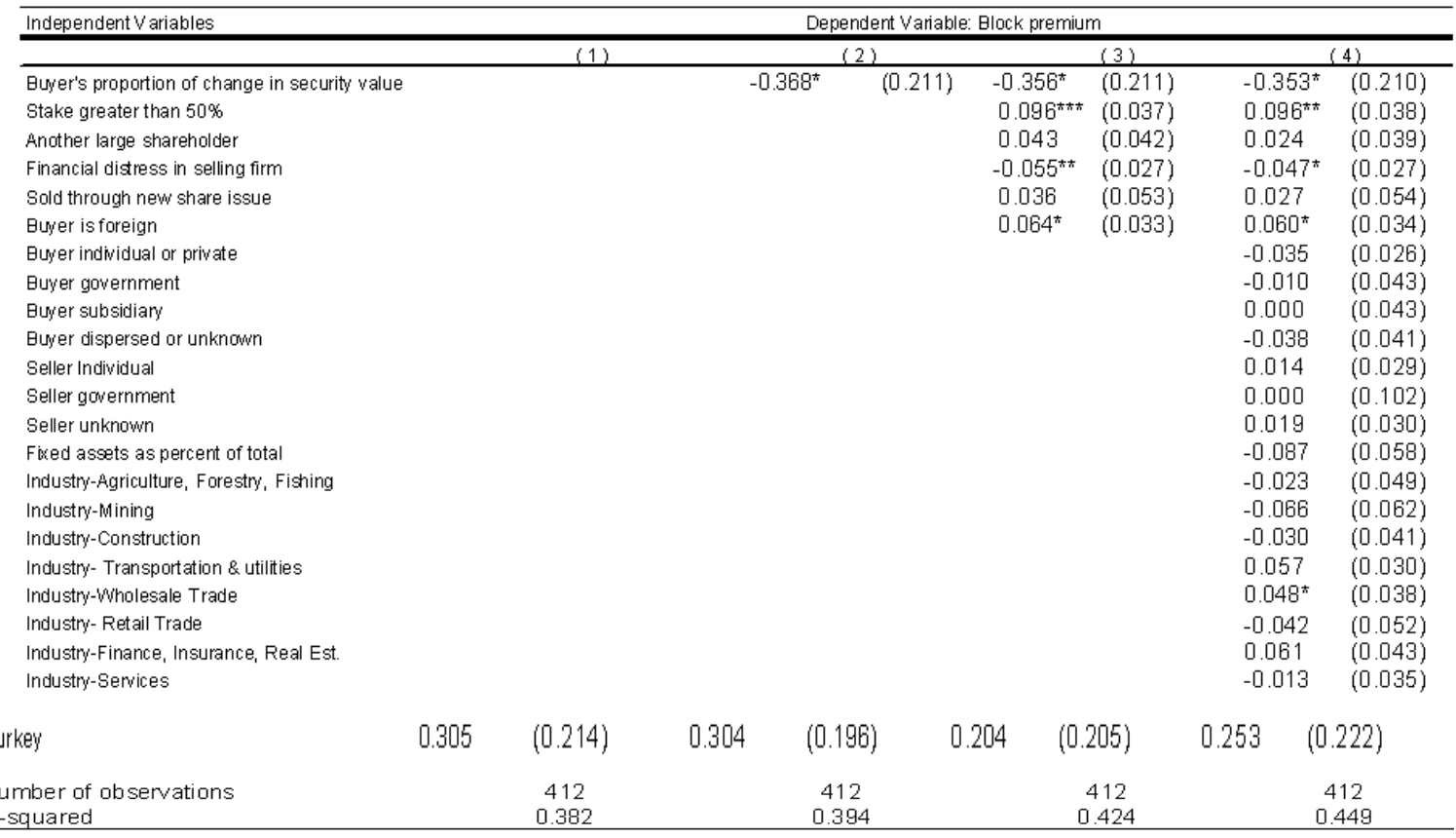

Source: DICK and ZINGALES (2001), p.47

Column 1 is the block premium as the dependent variable, Column (2) is the buyer's proportion of the difference in security value between the buyer and seller. Column (3) is several deal characteristics: whether it is a majority block, whether there is another large shareholder, whether the firm is in financialdistress, whether the block was created by issuing new shares, and whether the buyer is foreigner. Column (4)is several industry and seller/buyer characteristics: identity of the buyer (individual, government, subsidiary,dispersed), identity of the seller (individual, government, unknown), 2-SIC code industry dummies, and theproportion of fixed to total assets.

Regarding the analysis by Hekimoğlu and Tanyeri, their methodology was based on event-analysis. The observation period was composed of two main components: estimation period which between $t=-282$ and 30 and event period which is between $t=-30$ and +30 where $t=0$ was the day of the announcement of the transaction. Within this 312-day period, they look at a 3-day Cumulative Abnormal Returns calculation which 
reflected the value of any relevant control variable. Table 5 below give the results of the regression they conducted with the variation of control premiums that were observed in the sample data.

According to Table 5, Turkish stock markets commanded approximately 9 to $11 \%$ premiums for merger transactions that were completed in 3-day, 7-day or 11-day event windows, meaning 1, 3 and 5 days before and after announcement day $(t=0)$. The authors point out that these values are significantly lower than values observed in America and in Europe for the same event windows in different observation period. Taking, for example, the 3-day event period, the U.S. markets show 16 to $23 \%$ premiums while European markets have values in the range of 5 to $13 \% .^{52}$

They presume that the lower values in Turkish markets may reflect the characteristics of relatively less developed regulatory environments where leakage of information well before announcement dates may shave off the effects of announcements. Another reason may be the effect of the duration and procedural characteristics of regulatory processes that vary from one country to the other. One other factor may certainly be the ambiguity of the exact day of announcement, differences between official announcements and media coverage and so on.

Table 5: Cumulative Abnormal Returns

\begin{tabular}{|c|c|c|c|c|}
\hline & $\begin{array}{l}\text { 3-day } \\
{[-1,+1]}\end{array}$ & $\begin{array}{l}\text { 7-day } \\
{[-3,+3]}\end{array}$ & $\begin{array}{l}\text { 11-day } \\
{[-5,+5]}\end{array}$ & $\begin{array}{c}\# \text { of } \\
\text { Transactions }\end{array}$ \\
\hline Total Panel & $4,88 * * *$ & $5,94 * * *$ & $5,63 * * *$ & 125 \\
\hline \multicolumn{5}{|l|}{ Mergers } \\
\hline Positive & $8,56 * * *$ & $10,17 * * *$ & $9,82 * * *$ & 52 \\
\hline Negative & $2,25 * * *$ & $2,93 * *$ & $2,65 *$ & 73 \\
\hline Difference & $6,31 * * *$ & $7,24 * * *$ & $7,17 * *$ & \\
\hline \multicolumn{5}{|c|}{ Completed Transactions } \\
\hline Positive & $6,08 * * *$ & $7,65 * * *$ & $8,00 * * *$ & 83 \\
\hline Negative & $2,5 * *$ & 2,56 & 0,97 & 42 \\
\hline Difference & $3,58 *$ & $5,09 * *$ & $7,03 * *$ & \\
\hline \multicolumn{5}{|c|}{ Completed Mergers } \\
\hline Positive & $8,93 * * *$ & $10,96 * * *$ & $10,87 * * *$ & 42 \\
\hline Negative & $2,83^{* * *}$ & $3,4 * * *$ & $2,99 * *$ & 83 \\
\hline Difference & $6,1 * * *$ & $7,56 * *$ & $7,88 * *$ & \\
\hline
\end{tabular}

Source: HEKIMOĞLU, TANYERI (2013), p. 13-14

The significance of results were tested; $* * * * *$, and * represents statistical significance of 1 percent, 5 percent and 10 percent, respectively.

\section{CONCLUSION}

This paper has introduced a conceptual overview of the question of control share premiums that constitute an important dimension in corporate valuations. We have also looked briefly at two relatively comprehensive studies that examine the size of control premiums that were relevant at given time intervals in Turkish financial markets. Finally, we have looked at various methods that serve basis for the calculation of control premiums in merger and acquisition transactions in the market. Based on the theoretical arguments on the nature of "control value" and the observations we have noted in related empirical studies, we can summarize our conclusions in three main categories.

First of all, the legal basis of control value and the use of it by the controlling shareholders must be based on clear legal grounds. As noted in this paper, control means power and power means the capacity to compel others to actions on or compliance with decisions which others may or may not necessarily wish to undertake on their own will. As such, the creation and exercise of control value is essentially a legal question. We refer,

\footnotetext{
${ }^{52}$ Ibid., HEKIMOĞLU and TANYERI, p. 5.
} 
in this paper, specific examplary cases that trace the historic development of the legal doctrine that has shaped the meaning and the application of control value in relatively developed markets.

Consequently, we note that a) control value is essentially extraction of corporate value from other shareholders and transfering it to controlling part(ies)y; b) control value does not always imply positive incentives for the controlling part(ies)y, therefore, raises issues on additional legal and financial responsibilities and questions of burden sharing; $c$ ) control value must be related to cashflow enhancing and/or risk mitigating actions by the controlling part(ies)y and must be documented clearly and firmly, not only in financial terms but also on firm legal grounds.

Secondly, though control value is a critical factor in corporate valuations, it is fundamentally a case-specific factor. There are no commonly accepted percentages or guidelines, so-called no "rule of thumb" that define and govern the application of control values in corporations at a general level. It is also an area of inquiry that is very difficult to pursue academically or otherwise as access to relevant data and information is highly restricted. This is especially true where private market transactions are concerned. As a result, much of the academic work that is done on this topic is mainly confined to available information in public market transactions.

However, as the observations in public markets represent post-facto estimations that are calculated based on already completed transactions, they offer meaningful indications only as comparables in the assessments for new transactions. It is important to highlight here that these estimations do not represent financial attributes, only. Non-financial factors such level of social and political maturity in the respective societies (ssytemic factors) serve also as important inputs in determining the sizes and applications of control premiums. Last but not the least, regulatory practices bear direct effects on the issue of control premiums. Legislative actions and the structural characteristics of the relevant regulatory environment, especially with respect to protection of minority interests in corporations, act as limiting or relaxing factors on calculating control premiums in these markets.

Thirdly, we must propose a given methodology in calculating control premiums in overall valuation of companies that consider making acquisitions or being acquired themselves. We highlight clearly that the basis of control premiums would need to be stated in cash values and to be extracted from the account of holders of minority interests in the companies and accrued to the account of the conrolling part(ies)y. As such, "private benefits of control" approach provides the most meaningful and calculable basis for determining control premiums.

Fundamentally, control premiums originate from operational and financial management of the companies. They also originate from synergistic contributions of the controlling owners at the strategic level. Both levels present adequate and quantifiable data to estimate the cash equivalent of "private benefits of control. Estimated cashflows in this data, discounted at weighted average cost of capital (WACC) of the target company provide for us the present value of private benefits which is equal to the value of control premium in the respective company. Regarding the statement of the control value as percentage value, we argue that the control value be stated as percentage of the enterprise value rather then the equity value (as in, $P_{c}=V_{c} / V_{E}$ ). Considering that the estimates of control premium levels in market-driven calculations include the effects of "systemic factors," it is useful to compare the calculated control premiums with the estimated premiums in the market (comparables). The final level of premium is, then, determined as a function of the bargaining powers of respective parties to the transactions, i.e. the exchange value of the transaction. 


\section{REFERENCES}

\section{Primary Sources}

American Society of Appraisers, ASA Business Valuation Standards, BVS-VII;available at http://www.appraisers.org/docs/defaultsource/discipline bv/bv-standards.pdf?sfvrsn=0

Banking Regulatory and Supervision Authority, Financial Markets Report, No. 26, June 2012

Borsa Istanbul, Annual Report 2014.

Turkish Statistical Institute Data Base

Books

Berle, Adolf A. Means, Gardiner C. (1991), The Modern Corporation and Private Property, USA: Transaction Publishers, New Jersey.

Cornell, Bradford (1992), Corporate Valuation, Business One Irwin, USA: New York.

Gilson, Ronald, J. and Bernard, S. Black (1995), The Law and Finance of Corporate Acquisitions, 2nd ed., Foundation Press, New York.

Mercer, Christopher, Travis, Harms W. (2007), Business Valuation: An Integrated Theory, 2nd ed., USA: Wiley, New York

Prattt, Shannon (2008), Valuing a Business, 5th edition, USA: McGraw Hill, New York

Articles

Booth, Richard A. (2001), “Minority Discounts and Control Premiums in Appraisal Proceedings." October 4, 2001; available at: http://ssrn.com/abstract=285649

Coates, J.C.,Ownership, takeovers and EU law: how contestable should EU corporations be?; The Harvard John M. Olin Discussion Paper Series: http://www.law.harvard.edu/programs/olin_center/, Discussion Paper No. 450, 12/2003, ISSN 1045-6333

Cornell, Bradford (2013), Guideline Public Company Valuation and Control Premiums: An Economic Analysis; available at:

http://people.hss.caltech.edu/ bcornell/PUBLICATIONS/2013\%20Cornell\%20-\%20Control\%20Premiums.pdf

Damodaran, Ashwath (2005), "The Value of Control: Implications for Control Premiums, Minority Discounts and Voting Share Differentials;" available at: http://people.stern.nyu.edu/adamodar/pdfiles/papers/controlvalue.pdf

Dick, Alexander, Zingales, Luigi (2002), "Private Benefits of Control: An International Comparison; available at https://ideas.repec.org/p/nbr/nberwo/8711

Ernest and Young-istanbul, Mergers and Acquisitions Report Turkey, 2014.

Fishman, Jay E. (2013), "The Measurement and Application of Market Participant Acquisition Premiums," Appraisal Foundation Working Group-3 Discussion Draft, April 16, 2013.

Harms, Travis W. (2015), "The Market Participant Acquisition Premium," 2015 OIV International Business Valuation Conference, Milan, Italy, January 19, 2015:available at http://www.forumtools.biz/oiv/upload/TravisHarmsOIVPresentation.pdf

Hekimoğlu, Mert Hakan, Tanyeri, Başak (2011), "Stock Market Reactions to Mergers of Non-financial Turkish Firms;" available at: http://papers.ssrn.com/sol3/papers.cfm?abstract_id=1768015

Matthews, Gilbert (2008) “Misuse of control premiums in Delaware appraisals,”Business Valuation Review,27.

“Market Participant Acquisition Premiums," VCR Alert, November 2013.

Nath, Eric (1990), “Control premiums and minority interest discounts in private companies,"Business Valuation Review, 9.

Nath, Eric (1994), “A Tale of Two Markets,"Business Valuation Review, 13.

Nath, Eric W. (2011), “Best Practices Regarding Control Premiums; Comments regarding the Appraisal Foundation's White Paper on Control Premiums," Journal of Business Valuation 2011:2

Sepe, S.M. (2010), "Private Sale of Corporate Control: Why the European Mandatory Bid Rule is Inefficient,"Arizona Legal Studies Discussion Paper No. 10-29. Available at SSRN: http://ssrn.com/abstract=1086321

Pursel, Brad (2010), “Control Premiums; Application and Analysis”Business Valuation Publications LLC, article \# 11126, March 2010.

Schubert, Walt, Barenbaum, Les (1991) “Control Premiums and the Value of the Closely-held Firm," Journal of Small Business Finance, Vol. 1:2; available at: http//digitalcommons. pepperdine.edu/jef/vol1/iss2/5 